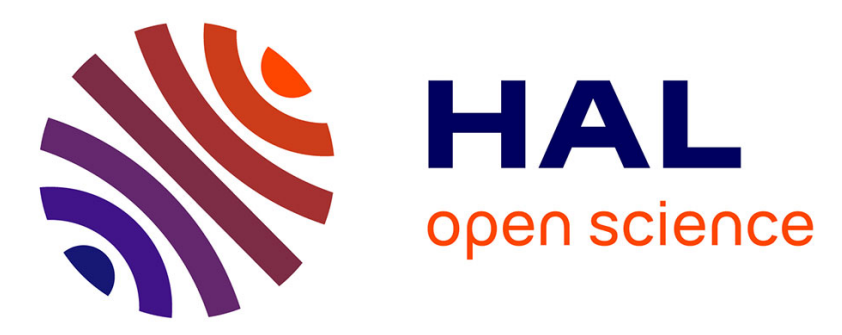

\title{
Electronic "Pockets of Effectiveness": E-governance and Institutional Change in St. Petersburg, Russia
}

\author{
Yury Kabanov, Andrei V. Chugunov
}

\section{To cite this version:}

Yury Kabanov, Andrei V. Chugunov. Electronic "Pockets of Effectiveness": E-governance and Institutional Change in St. Petersburg, Russia. 16th International Conference on Electronic Government (EGOV), Sep 2017, St. Petersburg, Russia. pp.386-398, 10.1007/978-3-319-64677-0_32 . hal-01702998

\section{HAL Id: hal-01702998 \\ https://hal.inria.fr/hal-01702998}

Submitted on 7 Feb 2018

HAL is a multi-disciplinary open access archive for the deposit and dissemination of scientific research documents, whether they are published or not. The documents may come from teaching and research institutions in France or abroad, or from public or private research centers.
L'archive ouverte pluridisciplinaire HAL, est destinée au dépôt et à la diffusion de documents scientifiques de niveau recherche, publiés ou non, émanant des établissements d'enseignement et de recherche français ou étrangers, des laboratoires publics ou privés. 


\title{
Electronic "Pockets of Effectiveness": E-Governance and Institutional Change in St. Petersburg, Russia
}

\author{
Yury Kabanov( ()$^{1}$ and Andrei V. Chugunov ${ }^{2}$ \\ ${ }^{1}$ National Research University Higher School of Economics, St. Petersburg, Russia \\ ykabanov@hse.ru \\ ${ }^{2}$ ITMO University, St. Petersburg, Russia \\ chugunov@egov-center.ru
}

\begin{abstract}
The paper explores the patterns and factors of e-governance development in ineffective institutional settings. Although it is assumed that most of e-projects in such countries failed, we argue that in some contexts such initiatives can survive in the hostile environment and achieve relatively positive results, leading to limited institutional changes. We adapt the pockets of effectiveness framework in order to analyze the Our Petersburg portal (St. Petersburg, Russia). Our findings suggest that such electronic "pockets" may emerge as a deliberate policy of the political elite in an attempt to make institutions work properly. The key factors of such projects' success relate to agency, namely the political patronage and control, policy entrepreneurship, as well as organization autonomy and the power of the initiative.
\end{abstract}

Keywords. E-government, e-governance, institutional change, pockets of effectiveness

\section{$1 \quad$ Introduction}

A substantial part of e-governance research aims at revealing when, how and if ICTs lead to institutional changes in public administration or citizen-government relations [3; 15]. In fact, a plethora of works has found little impact of the e-mechanisms on democratization and the quality of governance, especially in ineffective institutional contexts, developing, neopatrimonial ${ }^{1}$ or authoritarian countries [24; 27;30], limiting the role of such instruments to legitimation and PR [2; 34]. But is this always the case? If incumbents may be interested in malfunctioning institutions to gain rents [19], can they eventually make use of e-government as a working tool? Although ICTs can consolidate the regime and empower autocrats [20], can they in fact strengthen the state capacity [23]? For instance, some empirical findings suggest that such relatively successful examples can be found on the subnational level [26].

The research goal is hence to reveal the factors such effective e-governance instruments emerge in the potentially hostile (authoritarian or neopatrimonial) institu-

${ }^{1}$ For discussion on the concept of neopatrimonialism see [51] 
tional environment. To do this, we apply the pocket of effectiveness (PoE) concept [42] to the case of the Nash Peterburg (Our Petersburg, OP) portal, St. Petersburg, Russia, ${ }^{2}$ a government - initiated platform, launched in 2014, showing relative viability and effectiveness particularly against the overall ambiguous performance of the national initiatives $[19 ; 5 ; 9]$, and in the context of the Russian political regime [17]. We investigate if the OP portal is an example of PoE, and why.

\section{Factors of ICT-Enabled Institutional Change: "Pockets of Effectiveness Framework"}

The concepts like e-government, e-participation, e-democracy etc. have always been surrounded by myths and normative implications on better government and democracy. But challenged by reality, they often fail [4]. Potentially, the directions of ICT-led institutional change are different and overwhelming [36]. For instance, e-mechanisms can affect bureaucracy by reducing administrative discretion via the automated information systems [32:223-224; 40; 41], eliminating corruption [46;11], cutting the red tape [48], improving public services' delivery or enhancing participation [28; 31]. All improvements do not follow immediately and with necessity, though [13: 88-89; 12$]$.

The factors influencing the success of e-government are conceptualized differently. An important aspect is agency, or entrepreneurship [14], and its interaction with structures, i.e. institutions and organizational settings $[3 ; 15 ; 35 ; 50]$. Leadership and political power are crucial when bureaucracy is reluctant to changes and hinders the reform $[1 ; 44]$. Other possible factors include stakeholders' engagement, communication and feedback [33], public value and trust [6], institutional design [49; 6]. Plenty of research has been conducted so far to systemize all factors in one framework [38].

The problem is that ICT-enabled institutional change, as previous research shows, often emerges in polities with already sufficient institutional quality and democracy. Developing, neopatrimonial and authoritarian countries usually lag behind in terms of e-participation development [25]. Even when they have enough capacity to introduce technological advancements [47], new instruments serve other goals: to be a façade for legitimation, international socialization or investment [1; 34]. Even if a strong political will for reforms is observed, they usually fail due to the informal norms and rent-seeking behavior of public officials [19].

In such context, a full-scale reform cannot be accomplished successfully. However, in some cases scholars observe that new institutions and organizations can resist the hostile environment and show relatively effective performance. Such organizations are called pockets of effectiveness, or PoE - "public organizations that deliver public goods and services relatively effectively in contexts of largely ineffective governments" and "operate in politico-administrative systems that are primarily based on personal networks instead of ... impartiality and formal, law - based rules" [42]. Roll distinguishes several characteristics of the PoE: "relative effectiveness", contribution to public good and "persistence as PoE for at least three years" [43]. There is a ques-

${ }^{2}$ Our Petersburg Portal, http://gorod.gov.spb.ru [in Russian] 
tion why a PoE emerges, and several frameworks were proposed. The discussion is basically focused on what factors are necessary and sufficient. Based on Leonard and Roll [29; 42; 43], we may discern the following variables:

- political factors, including the strong leadership of the political elite, and its interest in effective institutions. As Leonard argues, the PoE is related to the "benefits and costs ... for the politically powerful groups" [29: 97];

- managerial factors, ranging from proper training, commitment and "merit-based recruitment" and "inclusive leadership" and entrepreneurship to the ability of a public organization's leader to get political support and protection, remaining "autonomous of an operational political direction" [29: 95];

- organizational and institutional factors, such as the autonomy and powers of the organization to perform their tasks through legal and enforcement mechanisms;

- other factors, distinguished by Roll include, for instance, PR and external pressures.

Although the studies on PoE mostly relate to developing countries in Africa, we suppose that this concept is applicable to any context when institutions do not work properly, such as Post-Soviet countries, including Russia [18]. In some cases, the creation of PoE becomes the final resort to increase governmental performance in time when a more overall reform is hindered by the existing institutions. The key implication of this framework to the e-governance studies is that the ICT - enabled instruments or public organizations may perform the functions of a PoE. The research strategy is to distinguish such successful cases and explain the factors of their success. We can draw several hypotheses from the framework. First, we hypothesize that egovernance initiatives can survive in the hostile institutional environment as a PoE, leading to some limited positive changes (H1). Secondly, we hypothesize that the development of PoE will depend on: 1) political control (H2), meaning the leadership and attention of the chief executive to the development of the policy; 2) institutional entrepreneurship (H3); 3) autonomy (H4) of the key executives in charge of OP.

\section{Case of PoE Emergence: Our Petersburg Portal}

\subsection{Research Design}

To accomplish the research goal of discovering an electronic PoE and explaining its emergence, we do the case study. We take the Our Petersburg Portal (OP), created by the government of St. Petersburg. The case selection is justified by the fact that St. Petersburg shows relatively high level of the regional e-government development. On the one hand, it does not have as much resources as another federal city, Moscow.

The first task is to discern the characteristics that attribute OP to the PoE. Namely, we need to conceptualize success. As PoE framework suggest, success can be understood as a relatively better service provision, internal efficiency and persistence. To explore if the OP meets these criteria, we explore the development of its institutional design, popularity with citizens and effectiveness in citizens' complaints resolution. The more elaborate the OP becomes, the more complaints it processes and the more 
spheres it covers, the more successful the OP is supposed to be. The empirical data here is the descriptive statistics on the OP functioning, gathered by the automatic monitoring system developed at the ITMO University [52] or provided by the city government, as well as official documents that regulate the OP.

The second task of revealing success factors, we have conducted five in-depth semi-structured interviews with public officials, related in various capacities to the OP emergence and operation. We asked them to share their own vision on how the OP had been initiated, on the role of decision-makers and civil servants, on the problems, current state and perspectives of the OP. The thematic and discourse analysis was then used to combine these subjective stories into a general, collective experience on the OP. Along with documental and mass media data, these interviews (some quotes are given) used to explore the formation and success factors.

\subsection{Our Petersburg Portal as an Emerging PoE}

Although the situation in Russia cannot be compared to the situation in some developing countries, it sill faces difficulties in maintaining effective institutions of good governance, mainly due to ineffective bureaucracy and informal ties [18], as well as corruption [22]. In this respect, the real impact of the e-governance is doubted [5]. Against this picture, St. Petersburg presents a relatively better picture compared to other regions. It is considered to be relatively democratic [39], having a relatively effective bureaucracy and quality of life. In May 2014 the St. Petersburg Government adopted the ambitious Strategy $2030,{ }^{3}$ aiming at restructuring the city administration, strengthening control and eliminating information asymmetry for better urban planning. In accordance with this, in 2015 the regional administrative reform was launched, to deliver quality service and implement new ICTs into the urban planning. ${ }^{4}$ The launch of the OP could serve this end.

The Portal was officially launched in early 2014 as a government - led portal, initiated by St. Petersburg Governor Georgy Poltavchenko. It serves to gather online complaints from citizens, devoted to the wide spectrum of urban problems, such as roads and housing etc., and process and solve them through the ICT with minimum delays. ${ }^{5}$ In short, to solve a problem related to the urban environment, a citizen needs to register in the OP and submit an application. Each registered complaint is classified and processed through the moderator / coordinator to the executive in charge of its resolution. Then the executive agency should report on the results.

It was neither the first project of that kind in Russia, nor the only platform for urban problems solution in the city. In 2012, a group of civil activists launched the online platform "Beautiful Petersburg" (BP). As a legal basis, the BP uses the federal legislature on citizens' addresses (Law 59 "On Handling Citizens' Appeals"), allowing their transmission in electronic form. ${ }^{6}$ Although it was novel for the e-governance

3 St. Petersburg 2030 Strategy, http://spbstrategy2030.ru/?page_id=102 [in Russian]

${ }^{4}$ Administrative reform in St. Petersburg, http://gov.spb.ru/gov/otrasl/c_information/adm_ref/ [in Russian]

${ }^{5}$ Our Petersburg Portal, http://gorod.gov.spb.ru [in Russian]

${ }^{6}$ Federal Law 59 On the Order of Consideration of Addresses from Citizens of the Russian Federation. Adopted on 02.05.2006, http://www.consultant.ru/document/cons_doc_LAW_59999/ [in Russian]. 
practices then, it could have in fact not been called true institutional innovation, as the internal bureaucratic workflow remained pretty much the same [10]. On the contrary, the OP provided a brand new and ambitious regional legislation.

The key agencies involved in innovation are the Committee on Information and Communication (CIC), headed by Ivan Gromov, dealing with technological issues, the Gubernatorial Control Board (GCB) in charge of the administrative and legal aspects, and the City Monitoring Center (CMC), as a moderator and information processing unit. The first version of the portal (fig. 1) was limited in scope, but required much effort in order to provide a technological and legal basis. As our interviewee notes, they needed to restructure all administrative workflow from "the Governor to housing offices and road services". Complaints were to reach the exact agency or municipality, and it was crucial to clarify the competence of all divisions and the ownership of each city object, from "roads to trash cans". The portal has been constantly modernizing. In 2015 the Interdepartmental Commission was established in order to resolve possible conflicts between the agencies. In 2016 the public control was introduced, when users could check the completion of a task. ${ }^{7}$

The recent scheme of the OP is presented in fig. 2. In theory, the OP implies an unprecedented transformation of bureaucratic practices. In comparison to the ordinary procedure, enshrined in Federal Law 59 used by the BP portal, it shortens the time for complaints' processing, and clarifies agencies' responsibilities and control. If Law 59 gives agencies 30 days to respond, in the case of the OP they should do it in 7 days or less. It cuts red tape and sets the interoperability of executive bodies based on ICT. So, the OP has been evolving as a PoE in legal and technological terms.

From the start, the new initiative had to compete with the abovementioned civic initiative, as well as to deal with the internal bureaucratic rigidity. The founder of the BP Krasimir Vransky accused the OP of being a stillborn PR project, ${ }^{8}$ while shortened time limits and procedures negatively affected the ordinary bureaucratic workflow, making Ivan Gromov "the personal enemy of some districts' administrations".

Our interviewees emphasize that the implementation was challenged by a "silent rebellion" against the OP and the CIC, especially from the housing services. The latter had to use the portal, but could discredit the portal, attempting to present reports with Photoshop-edited images, or even threaten the applicants. Some services adapted to new regulations by creating separate positions or units to handle complaints, which protect the rest of the structure from changes. Hence, the establishment of a disputeresolving Interdepartmental Commission was a timely measure. The institutional resistance is constant, as new executive agencies are included into the system, being "not eager to help in developing technological routes of applications processing" and "trying to postpone it by any means".

Despite this, the OP seems to have won the competition for efficiency and popularity against the BP by the end of 2015 (fig. 3). Official statistics claim that as of February 2016, about 169 thousand urban problems out of 193,5 thousand reported via the

\footnotetext{
${ }^{7}$ Changes in the work of Our Petersburg Portal, http://gorod.gov.spb.ru/content/news/36/ [in Russian]

${ }^{8}$ Portal for Self-Glorification, https://www.zaks.ru/new/archive/view/127361 [in Russian]

${ }^{9}$ Ivan Gromov's speech on the IT Forum, 2015. Authors' notes.
} 
portal were resolved. ${ }^{10}$ Our interviewees suggest that the key achievement of the OP is the increase in efficiency and quality of governance. The portal is expanding in terms of problem categories and the agencies involved (Table 1).

While it positively affects the principal - agent problem, discretion and corruption by transparent rules and meaningful control mechanisms, it in unclear if the portal is viable in the long run. The goal of the OP was not to reform the entire system of governance from scratch. All previous legal regulations, such as Federal Law 59, remain in power, with persisting red tape and inefficiency problems. As North argues, formal institutions can be easily altered, but time is needed to change informal rules [37].

To summarize here, we suppose that OP represents a case of PoE in several respects. It was deliberately excluded from a different legislative basis, creating an alternative system of urban governance beyond the persistent informal norms. It meets the criteria of relative effectiveness, persistence and contribution to public goods, and manages to survive and develop in the potentially hostile institutional environment. It proves the thesis that sometimes the incumbents need working e-governance instruments that function well beyond legitimation, supporting our hypothesis (H1).

\subsection{Factors of PoE Emergence}

Political Control. It's quite clear from the interviews' analysis, that the role of the Governor in success of the OP is crucial. The positioning of the portal as a gubernatorial initiative gave necessary incentives to comply with new rules. The gubernatorial powers and executive domination in Russia have significantly increased since the 2000s [21]. Supplemented by the so-called power vertical, a hierarchal system of governance and informal rules [16], it made governors the key political actors able to concentrate resources in order to implement policies, provided there are incentives. Although the launch of the portal might have been linked to the election campaign, the main rationale, we argue, was to increase the gubernatorial control over bureaucracies at all levels, centralizing the system of governance and strengthening political power. Such goal seems more plausible, as neither the OP was banned after the elections, nor the OP substantially increased the level of citizen engagement in decisionmaking [10]. The context is important as well: in 2012 e-government and eparticipation became a national priority, and Moscow was the first to initiate an innovative portal for urban problems reports. Hence, the OP could help St. Petersburg show loyalty to the federal policy and be competitive against other regions.

Such personal political patronage was accompanied by effective control mechanisms. The GCB was empowered to formulate the reports on executive discipline. These documents contain the indicators of agencies' work with the OP. Each executive body should report on a monthly basis. The Governor may take disciplinary measures on the results. As formulated by Ivan Gromov, “... the Governor of St. Petersburg constantly pays attention to it [the OP]. If he didn't systematically check it,

\footnotetext{
${ }^{10}$ Our Petersburg Portal, http://gorod.gov.spb.ru [in Russian]
} 
the portal wouldn't have raised so high". ${ }^{11}$ The transparency of the portal, allowing mass media and citizens to control the work of the executive agencies, has contributed to the gubernatorial control. Falsified images in reports that were found by mass media were met with severe criticism from the Governor. ${ }^{12}$ The existing "power vertical" rendered the transmission of gubernatorial incentives through all bureaucratic levels very fast, contributing to the success of the OP. Though it was necessary for the rapid implementation, it seems to be insufficient, as the operative control is needed. Otherwise, when the patronage is over, the initiative will fade with comparable velocity.

Institutional Entrepreneurship. The role of institutional entrepreneurs is crucial in policy changes [14]. Somebody had to persuade the Governor to implement the policy and level the interests of political actors. Here we can mention the role of Ivan Gromov, a former CIC head, who performed the classical role of an institutional entrepreneur. He was appointed in 2012 when, as he noted, the regional IT system needed more centralization and economic efficiency. ${ }^{13}$ His motivation to launch the OP is not clear, but the easy answer obtained from an interview, "he just wanted something working properly to help people". Due to his previous work in Moscow, he might have learnt about the success of a similar project.

Despite his motivation, Gromov possessed sufficient political authority, being a trustee member of the Governor's team. ${ }^{14}$ He managed to acquire political support of his initiative, and demonstrated "inclusive leadership" to motivate the employees. To leverage the system of administration, Gromov took the medium position between the Governor, the GCB and the rest of the executive bodies, as he had to sustain the political interest in the OP and ICTs in general, on the one hand, and amortize the possible negative effects on the other. Until 2015, when he was appointed the head of one of St. Petersburg's districts, he had supported (and still does) the project.

Organizational Autonomy. In 2015 Gromov resigned from his position as CIC head, but it did not affect the efficiency of the OP. Is it inertia or regularity? From the framework, we know that the autonomy and sufficient powers are important for the PoE emergence and survival. Furthermore, as literature suggests, the ICT can lead to a reinforcement of the existing power relations [45], allowing those controlling the ICTs to concentrate more recourses and authority.

This hypothesis is partially confirmed in our case. During the OP establishment, the CIC, led by Gromov, has sufficiently raised its status, mostly informally through the association to the gubernatorial initiative. The importance of ICTs in public administration has also generally increased. In terms of finance allocation, the CIC is the key recipient of funds with an annual average budget of 6 billion rubles, ${ }^{15}$ and the regional expenses on IT remain one of the highest in Russia. ${ }^{16}$ Sufficient resources

Ivan Gromov: “Our Petersburg” Solves Problems Quickly, http://www.spbdnevnik.ru/news/2016-08-30/nash-sanktpeterburg--reshaeyt-problemy-bystro/ [in Russian].

12 Governor: The official who repaired road with Photoshop is fired,http://www.fontanka.ru/2016/11/29/068/ [in Russian]

St. Petersburg: Informatization, http://www.tadviser.ru/index.php/ [in Russian]; New St. Petersburg IT Director, http://www.cnews.ru/news/top/novyj_itdirektor_sanktpeterburga [in Russian]

14 Persona: Ivan Gromov, http://www.tadviser.ru/index.php/Персона:Громов_Иван_Александрович [in Russian

15 Committee on Information and Communications of St. Petersburg, http://www.tadviser.ru/index.php/ Компания:Комитет по информатизации и связи Санкт-Петербурга [in Russian]

16 Informatization of Regions: Russian Market, http://www.tadviser.ru/index.php/Статья:Информатизация_регионов_(рынок_России) [in Russian] 
and patronage have provided the CIC with sufficient autonomy and status to implement the OP and other projects. However, the raise in status was implicit, as no changes in the administrative position of the committee occurred.

Crucial is that the successful implementation of the OP helped to achieve new powers in adjacent spheres, mainly in the administrative reform. First, in 2014 the division in charge for developing new administrative procedures was transferred from the Committee on Executive Agencies under the CIC. The Committee took responsibilities on the administrative reform in the area of electronic services and interdepartmental interaction. As the reform itself was connected to the development of the ICT infrastructure, the CIC acquired new opportunities to influence decision-making on the informatization of government. Second, the CIC became responsible for the Commission on administrative reform (Gromov was appointed its deputy head), raising its steering role. ${ }^{17}$ Although the CIC has never been a sanctioning body, the CIC managed to raise its own status and autonomy and secure the development of the OP.

Hence, we can summarize that the case study confirms the hypotheses that the political control (H2), institutional entrepreneurship (H3) and organizational autonomy (H4) became the key factors of the PoE emergence.

\section{Conclusion}

Our findings from the case of the OP contribute to the knowledge on e-governance and institutional change in several respects. First, we suggest the PoE can be a valuable research framework to be used in e-governance studies. It helps to grasp an ambiguity of e-governance projects in ineffective institutional settings, and its heuristic value is linked to the variety of hypotheses on why such electronic pockets of effectiveness emerge and persist.

Secondly, the research expands, and to a certain degree challenges the opinion that e-governance projects cannot function properly in ineffective institutional settings. Although most e-mechanisms are in fact legitimacy tools, in some cases they can serve incumbents better as working instruments, positively affecting the institutional development and public services provision. Here we can refer to one of our interviewees, who said that "no matter whether it were a PR-action, if it achieved real results and benefited the citizens".

The case of the "Our Petersburg" Portal provides an excellent example of such PoE, and proves that such electronic pockets can emerge and survive. Our study shows the crucial importance of agency in creating and maintaining successful e-mechanisms, namely the political control, institutional entrepreneurship and the organizational autonomy.

It is important to continue the analysis to and to compare the OP with other cases in Russia and abroad.

$17 \begin{aligned} & \text { Resolution of } \\ & \text { http://gov.spb.ru/law?d\&nd=822403644\&prevDoc=537976863 [in Russian] }\end{aligned}$ 


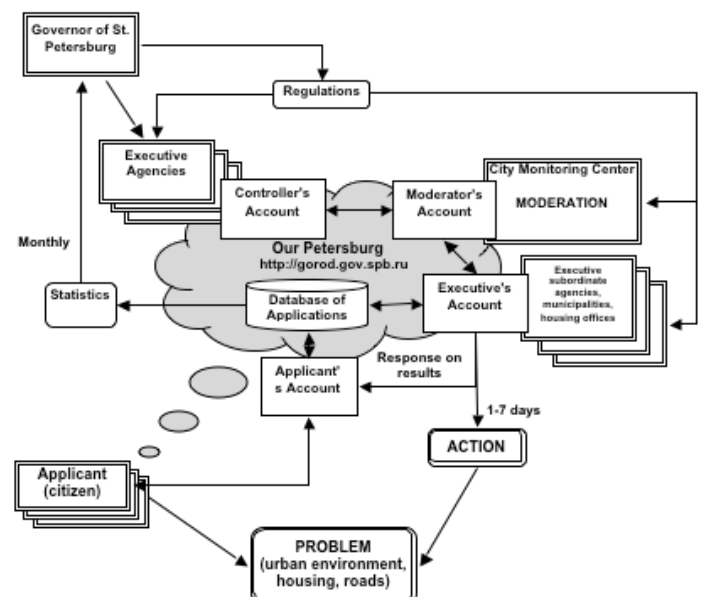

Fig. 1. The OP Portal's Technological and Institutional Ecosystem, Version of 2014. Source: Authors' picture based on open documents.

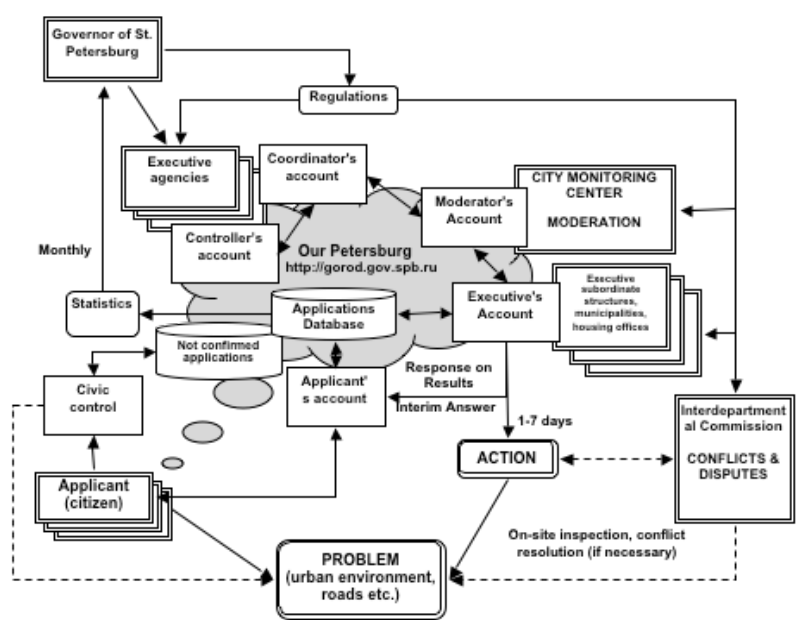

Fig. 2. The OP Portal's Technological and Institutional Ecosystem, Version of 2016. Source: Authors' picture based on open documents.

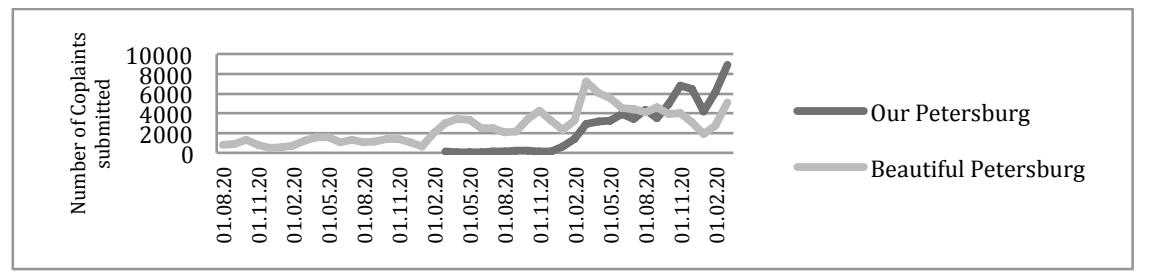

Fig. 3. The number of complaints submitted via the BP and OP portals, 2012 - 2016. Source: http://analytics.egov.ifmo.ru/ 
Table 1. Indicators of OP Growth, 2014-2016

\begin{tabular}{llll}
\hline \multicolumn{1}{c}{ Indicator } & $\mathbf{2 0 1 4}$ & $\mathbf{2 0 1 5}$ & $\mathbf{2 0 1 6}$ \\
Categories of complaints & 59 & 140 & 179 \\
Number of executive agencies involved & 23 & 45 & 56 \\
\hline
\end{tabular}

Source: Authors' calculations

\section{References}

1.Ahn, M. J., Bretschneider, S.: Politics of e-government: e-government and the political control of bureaucracy. Public Administration Review, 71(3), 414-424 (2011).

2.Åström, J., Karlsson, M., Linde, J., \& Pirannejad, A.: Understanding the rise of e-participation in non-democracies: Domestic and international factors. Gov.Inf.Q., 29(2), 142-150 (2012). doi: 10.1016/j.giq.2011.09.008

3.Barrett, M., Grant, D., Wailes, N.: ICT and organizational change introduction to the special issue. The Journal of Applied Behavioral Science. 42 (1), 6-22 (2006). doi: $10.1177 / 0021886305285299$

4.Bekkers, V., Homburg, V.: The myths of e-government: Looking beyond the assumptions of a new and better government. The Information Society, 23(5), 373-382 (2007). doi: 10.1080/01972240701572913

5.Bershadskaya, L., Chugunov, A., Trutnev, D.: e-Government in Russia: is or seems? In: Proceedings of the 6th International Conference on Theory and Practice of Electronic Governance, 22-25 October 2012, pp. 79-82. ACM, New York (2012). doi:10.1145/2463728.2463747

6.Bertot, J. C., Jaeger, P. T., Grimes, J. M.: Using ICTs to create a culture of transparency: Egovernment and social media as openness and anti-corruption tools for societies. Gov.Inf.Q., 27(3), 264-271 (2010). doi: 10.1016/j.giq.2010.03.001

7.Buffat, A.: Street-level bureaucracy and e-government. Public Management Review, 17(1), 149-161 (2015). doi: 10.1080/14719037.2013.771699

8.Chadwick, A.: Web 2.0: New challenges for the study of e-democracy in an era of informational exuberance. I/S: Journal of Law and Policy for the Information Society, 4(3), 9-42 (2008).

9.Chugunov, A. V., Kabanov, Y., Zenchenkova, K.: Russian e-Petitions Portal: Exploring Regional Variance in Use. In: 8th IFIP WG 8.5 International Conference, ePart 2016, Guimarães, Portugal, September 5-8, 2016, Proceedings, 109-122, Springer (2016). doi: 10.1007/978-3319-45074-2 9

10.Chugunov, A.V., Kabanov, Y., Misnikov, Y.: Citizen versus Government or Citizen with Government: A Tale of Two e-Participation Portals in One City (A Case of Saint - Petersburg, Russia). Forthcoming

11.Elbahnasawy, N. G.: E-government, internet adoption, and corruption: an empirical investigation. World Development, 57, 114-126(2014). doi: 10.1016/j.worlddev.2013.12.005

12.Fountain, J. E.: On the effects of e-government on political institutions. In: Kleinman, D.E., Moore, K. (eds.) Routledge handbook of science, technology, and society, 462-478, Routledge (2014).

13.Fountain, J. E.: Building the virtual state: Information technology and institutional change. Brookings Institution Press (2004).

14.Garud, R., Hardy, C., \& Maguire, S.: Institutional entrepreneurship as embedded agency: An introduction to the special issue. Organization Studies. 28 (7), 957-969 (2007). doi: $10.1177 / 0170840607078958$ 
15.Gascó, M.: New technologies and institutional change in public administration. Social science computer review, 21 (1), 6-14 (2003). doi: 10.1177/0894439302238967

16.Gel'man, V., \& Ryzhenkov, S.: Local regimes, sub-national governance and the 'power vertical' in contemporary Russia. Europe-Asia Studies, 63(3), 449-465 (2011). doi: $10.1080 / 09668136.2011 .557538$

17.Gel'man, V.: The rise and decline of electoral authoritarianism in Russia. Demokratizatsiya, 22(4), 503-522 (2014).

18.Gel'man, V., Starodubtsev, A.: Opportunities and Constraints of Authoritarian Modernisation: Russian Policy Reforms in the 2000s. Europe-Asia Studies, 68(1), 97-117 (2016). doi: $10.1080 / 09668136.2015 .1113232$

19.Gel'man, V.: The vicious circle of post-Soviet neopatrimonialism in Russia. Post-Soviet Affairs, 32(5), 455-473 (2016). doi: 10.1080/1060586X.2015.1071014

20.Göbel, C.: The information dilemma: How ICT strengthen or weaken authoritarian rule. Statsvetenskaplig tidskrifts arkiv, 115 (4), 385-402 (2013);

21.Golosov, G. V., Konstantinova, M.: Gubernatorial Powers in Russia: The Transformation of Regional Institutions Under the Centralizing Control of the Federal Authorities. Problems of Post-Communism, 63(4), 241-252 (2016). doi: 10.1080/10758216.2016.1146906

22.Goncharov D. V., Shirikov A.: Public Administration in Russia. In: Liebert, S., Condrey, S. E., Goncharov, D. V. Public Administration in Post-communist Countries: Former Soviet Union, Central and Eastern Europe, and Mongolia, Boca Raton: CRC Press, 23-43 (2013).

23.He, B., Warren, M. E.: Authoritarian deliberation: The deliberative turn in Chinese political development. Perspectives on politics, 9(02), 269-289 (2011). doi: $10.1017 /$ S 1537592711000892

24.Heeks, R.: Most egovernment-for-development projects fail: how can risks be reduced? iGovernment Working Paper Series. Vol. 14. Manchester: Institute for Development Policy and Management, University of Manchester (2003).

25.Jho, W., \& Song, K. J.: Institutional and technological determinants of civil e-Participation: Solo or duet?. Gov.Inf.Q., 32(4), 488-495 (2015). doi: 10.1016/j.giq.2015.09.003

26.Johnson, E., Kolko, B.: e-Government and transparency in authoritarian regimes: comparison of national-and city-level e-government web sites in Central Asia. Digital Icons: Studies in Russian, Eurasian and Central European New Media, 3, 15-48 (2010).

27.Katchanovski, I., La Porte, T.: Cyberdemocracy or Potemkin e-villages? Electronic governments in OECD and post-communist countries. Int. J. of Public Administration, 28 (7-8), 665681 (2005). doi: 10.1081/PAD-200064228

28.Kim S., Lee J.: E-participation, transparency, and trust in local government. Public Administration Review, 72 (6), 819-828 (2012). doi: 10.111/j.1540-6210.2012.02593.x

29.Leonard, D. K.: 'Pockets' of effective agencies in weak governance states: Where are they likely and why does it matter? Public Adm. and Development, 30(2), 91-101 (2010)

30.Linde, J., Karlsson, M.: The Dictator's New Clothes: The Relationship Between E-Participation and Quality of Government in Non-Democratic Regimes. Int. J. of Public Administration, 36 (4), 269-281 (2013). doi: 10.1080/01900692.2012.757619

31.Linders, D.: From e-government to we-government: Defining a typology for citizen coproduction in the age of social media. Gov.Inf.Q., 29(4), 446-454 (2012). doi: 10.1016/j.giq.2012.06.003

32.Lipsky, M. (2010). Street-level bureaucracy, 30th ann. Ed.: dilemmas of the individual in public service. Russell Sage Foundation.

33.Luna-Reyes, L. F., Gil-Garcia, J. R.: Digital government transformation and internet portals: The co-evolution of technology, organizations, and institutions. Gov.Inf.Q., 31(4), 545-555 (2014). doi: 10.1016/j.giq.2014.08.001 
34.Maerz, S. F.: The electronic face of authoritarianism: E-government as a tool for gaining legitimacy in competitive and non-competitive regimes. Gov.Inf.Q., 33(4), 727-735 (2016). doi: 10.1016/j.giq.2016.08.008

35.Meijer, A.J., Zouridis, S.: E-government as Institutional Transformation. In: Khosrow-Pour, M. (ed.) Innovations through Information Technology, Idea Group, Hershey PA, 565 - 568 (2004).

36.Nograšek, J., Vintar, M.: E-government and organisational transformation of government: Black box revisited?. Gov.Inf.Q., 31(1), 108-118 (2014). doi: 10.1016/j.giq.2013.07.006

37.North, D. C.: Institutions, institutional change and economic performance. Cambridge university press, NY (1990).

38.Panopoulou, E., Tambouris, E., \& Tarabanis, K.: Success factors in designing eParticipation initiatives. Information and Organization, 24(4), 195-213 (2014). doi: 10.1016/j.infoandorg.2014.08.001

39.Petrov, N., Titkov, A.: Rating of Democracy by Moscow Carnegie Center: 10 Years in Service. Moscow Carnegie Center, Moscow (2013).

40.Reddick, C. G., Abdelsalam, H. M., \& Elkadi, H.: The Influence Of E-Government On Administrative Discretion: The Case Of Local Governments In Egypt. Public Administration and Development, 31(5), 390-407 (2011). doi: 10.1002/pad.615

41.Reddick, C. G.: Citizen interaction with e-government: From the streets to servers? Gov.Inf.Q., 22(1), 38-57 (2005). doi: 10.1016/j.giq.2004.10.003

42.Roll, M. (Ed.). The Politics of Public Sector Performance: Pockets of effectiveness in developing countries. Routledge (2014).

43.Roll, M.: The state that works. Pockets of effectiveness as a perspective on stateness in developing countries. Institut für Ethnologie und Afrikastudien, Johannes Gutenberg-Universität. Working Paper Nr. 128 (2011);

44.Schlæger, J.: Digital Governance and Institutional Change: Examining the Role of EGovernment in China's Coal Sector. Policy \& Internet, 2(1), 37-61 (2010). doi: 10.2202/19442866.1014

45.Schlæger, J.: E-Government in China: Technology, Power and Local Government Reform. Routledge (2013)

46.Shim, D. C., Eom, T. H.: E-government and anti-corruption: Empirical analysis of international data. Intl Journal of Public Administration, 31(3), 298-316 (2008). doi: $10.1080 / 01900690701590553$

47.Stier, S.: Political determinants of e-government performance revisited: Comparing democracies and autocracies. Gov.Inf.Q., 32(3), 270-278 (2015). doi: 10.1016/j.giq.2015.05.004

48.Welch, E. W., Pandey, S. K.: E-government and bureaucracy: Toward a better understanding of intranet implementation and its effect on red tape. Journal of Public Administration Research and Theory, 17(3), 379-404 (2007). doi: 10.1093/jopart/mul013

49.Wright, S., \& Street, J. Democracy, deliberation and design: the case of online discussion forums. New media \& society, 9(5), 849-869 (2007). doi: 10.1177/1461444807081230

50.Yang, K.: Neoinstitutionalism and E-Government Beyond Jane Fountain. Social Science Computer Review, 21(4), 432-442 (2003). doi: 10.1177/0894439303256508

51.Erdmann, G., Engel, U.: Neopatrimonialism reconsidered: critical review and elaboration of an elusive concept. Commonwealth \& Comparative Politics, 1 (45), 95 - 119 (2007). doi: $10.1080 / 14662040601135813$

52.Chugunov, A. V., Kabanov, Y., Zenchenkova, K.: E-Participation Portals Automated Monitoring System for Political and Social Research. In: Digital Transformation and Global Society. Conference, DTGS 2016, St. Petersburg, Russia, June 22-24, 2016, Revised Selected Papers, 290 - 298, Springer (2016). doi: 10.1007/978-3-319-49700-6_27 